\title{
ANALISIS PERHITUNGAN, PENYETORAN DAN PELAPORAN PAJAK PERTAMBAHAN NILAI (PPN) PADA PT. EMIGAS SEJAHTERA
}

\author{
Fadhlurrahmah Santoso $^{1}$, Jullie J. Sondakh ${ }^{2}$, Natalia Y.T Gerungai ${ }^{3}$ \\ 1,2,3 Jurusan Akuntansi, Fakultas Ekonomi dan Bisnis, Universitas Sam Ratulangi, Jl. Kampus Bahu, Manado, \\ 95115, Indonesia \\ E-mail : santosofara@gmail.com
}

\begin{abstract}
The aim of this research was to know whether the Value Added Tax calculation, subsmission and reporting at PT. Emigas Sejahtera, was suitable with the Law No. 42 Years 2009 about Value-Added Tax and Luxuries Tax. This type of research is descriptive with qualitative approach. The data collecting techniques done were interview and documentation. The steps taken to analyze the acquired data were done in two phases, they were (1) analyzing the Value-Added Tax in debt calculation based on the Law No. 42 Tahun Years 2009 about Value-Added Tax and Luxuries Tax, and (2) analyzing the Value-Added Tax subsmission and reporting based on the Law No. 42 Years 2009 about Value-Added Tax and Luxuries Tax. The result of the research showed that the Value-Added Tax calculation was suitable with the Law No. 42 Years 2009 about Value-Added Tax and Luxuries Tax. While for VAT subsmission and reporting, PT. Emigas Sejahtera has been delayed in subsmission and reporting Value-Added Tax.
\end{abstract}

Keywords: Calculation, Subsmission, and Reporting VAT

\section{PENDAHULUAN}

Dalam APBN dijelaskan sumber-sumber pendapatan negara dari dalam negeri dan hibah. Pendapatan negara dari dalam negeri diperoleh dari pajak dan bukan pajak. Pajak adalah kewajiban yang harus dibayar masyarakat kepada pemerintah untuk kegiatan pembangunan di semua bidang. Peran penerimaan pajak bagi negara menjadi sangat dominan di dalam menunjang jalannya roda pemerintahan. Salah satu sumber penerimaan pajak yang paling potensial adalah berasal dari Pajak Pertambahan Nilai.

Pajak Pertambahan Nilai adalah golongan pajak tidak langsung yang bersifat objektif dan dipungut oleh pemerintah pusat. Pajak Pertambahan Nilai merupakan pajak yang dikenakan kepada Orang Pribadi atau Badan karena mengkonsumsi Barang Kena Pajak dan/atau didalam Daerah Pabean. Pada dasarnya setiap barang dan jasa adalah Barang Kena Pajak atau Jasa Kena Pajak, kecuali ditentukan lain oleh Undang-Undang No. 42 Tahun 2009 tentang Pajak Pertambahan Nilai Barang dan Jasa dan Pajak Penjualan atas Barang Mewah. Siapapun subjeknya masyarakat mampu maupun yang kurang mampu, ataupun masyarakat yang muda maupun tua, akan dikenakan Pajak Pertambahan Nilai selama mereka mengonsumsi Barang Kena Pajak atau Jasa Kena Pajak didalam Daerah Pabean.

Jika dilihat dari penerapan PPN seringkali menimbulkan masalah sehingga menarik untuk dijadikan objek penelitian. Setiap bulan perusahaan yang telah dikukuhkan sebagai Pengusaha Kena Pajak dan telah mempunyai Nomor Pokok Wajib Pajak (NPWP) harus menghitung pajak, menyetor pajak, serta melaporkan kewajiban pajaknya. Dikarenakan keberadaanya sangat penting untuk kelangsungan ekonomi negara Indonesia, maka perhitungan penyetoran serta pelaporan pajak tersebut harus dilakukan secara tepat dan benar. Karena bisa menjadi tolak ukur ketika membuat rencana yang tepat untuk kedepannya.

PT. Emigas Sejahtera merupakan Agen LPG tabung 3Kg yang bekerja sama dengan PT. Pertamina untuk menyalurkan LPG $3 \mathrm{Kg}$ ke berbagai pangkalan yang berada di 
Kabupaten Minahasa. Dengan demikian, PT. Emigas Sejahtera juga dikenakan Pajak Pertambahan Nilai (PPN). Pada PT. Emigas Sejahtera terdapat masalah dalam penerapan Pajak Pertambahan Nilainya yaitu pernah terjadi keterlambatan penyetoran dan pelaporan Pajak Pertambahan Nilai (PPN) maka harus membayar sanksi 2\% karena terlambat menyetor dan denda sebesar Rp 500.000 karena terlambat melapor. Penelitian ini bertujuan untuk mengetahui apakah perhitungan, penyetoran dan pelaporan Pajak Pertambahan Nilai yang dilakukan PT. Emigas Sejahtera telah sesuai peraturan perpajakan yang berlaku yakni Undang-Undang Nomor 42 Tahun 2009 tentang Pajak Pertambahan Nilai dan Pajak Penjualan atas Barang Mewah.

\section{TINJAUAN PUSTAKA}

Akuntansi. Menurut Horngren et al., yang dikutip oleh Pontoh (2013:1), akuntansi adalah sebuah sistem informasi yang mengukur aktivitas sebuah bisnis, kemudian memproses data menjadi sebuah laporan, dan mengkomunikasikan hasilnya kepada para pengambil keputusan. Menurut Warren, Reeve, dan Duchac (2017:9), definisi akuntansi yakni suatu sistem informasi yang dapat menyajikan laporan untuk para pemangku kepentingan tentang suatu aktivitas ekonomi perusahaan dan juga kondisi yang ada pada perusahaan.

\section{Dasar Pajak Di Indonesia}

Pengertian Pajak. Soemitro mengartikan pajak merupakan iuran masyarakat kepada kas negara seperti yang telah ditetapkan oleh undang-undang yang bersifat memaksa dan tidak mendapatkan jasa timbal balik atau kontraprestasi secara langsung dan dimanfaatkan untuk membiayai pengeluaran negara (Mardiasmo, 2018:3). Menurut Djajadiningrat yang dikutip oleh Resmi (2013:1), pajak merupakan kewajiban untuk memberikan sebagian kekayaan ke pada negara dikarenakan kondisi, kejadian, dan suatu perbuatan yang memberikan kedudukan tertentu, tapi itu bukan suatu hukuman, menurut aturan yang dibuat oleh pemerintah yang bersifat memaksa, tapi negara tidak melakukan jasa timbal balik secara langsung untuk menjaga kesejahteraan masyarakat.

Fungsi Pajak. Menurut Mardiasmo (2018:4), pajak memiliki dua fungsi sebagai berikut:

1. Sebagai sumber pendanaan pemerintah untuk membayar pengeluaran negara.

2. Sebagai sarana mengatur dalam lingkungan sosial dan ekonomi.

\section{Pajak Pertambahan Nilai}

Pengertian Pajak Pertambahan Nilai. Pengertian Pajak Pertambahan Nilai menurut Waluyo (2017:3), yaitu pajak yang dikenakan karena mengkonsumsi barang maupun jasa yang ada di dalam negeri (di dalam daerah pabean).

Subjek Pajak. Subjek Pajak Pertambahan Nilai yaitu Pengusaha yang telah mengukuhkan diri menjadi (Pengusaha Kena Pajak) dan memiliki penghasilan bruto lebih dari Rp. 4.800.000.000 (empat miliar delapan ratus juta rupiah) sesuai dengan Peraturan Menteri Keuangan Republik Indonesia Nomor 197/PMK.03/2013. Pengusaha yang menjual Barang Kena Pajak dan/atau menyerahkan Jasa Kena Pajak berdasarkan Undang-Undang No. 42 Tahun 2009.

Objek Pajak. Pajak Pertambahan Nilai dikenakan atas (Mardiasmo, 2018:330):

1. Penjualan Barang Kena Pajak (BKP) di Daerah Pabean oleh PKP.

2. Impor Barang Kena Pajak (BKP).

3. Menyerahkan Jasa Kena Pajak (JKP) di Darah Pabean oleh PKP.

4. Pemakaian Barang Kena Pajak Tidak Berwujud di dalam Daerah Pabean yang berasal dari luar Daerah Pabean.

5. Mengekspor Barang Kena Pajak Berwujud atau Tidak Berwujud oleh Pengusaha Kena Pajak. 
6. Aktivitas membangun sendiri yang diadakan tidak dalam aktivitas usaha oleh orang pribadi.

Dasar Pengenaan Pajak Pertambahan Nilai. Sesuai dengan Pasal 8A Ayat 1 UndangUndang No. 42 tahun 2009, Dasar Pengenaan Pajak ialah: harga jual, penggantian, nilai impor, nilai ekspor, dan nilai lain.

Mekanisme Pengenaan Pajak Pertambahan Nilai. Mekanisme pengenaan Pajak Pertambahan Nilai dapat digambarkan sebagai berikut (Mardiasmo, 2018:335):

1. Saat menjual Barang Kena Pajak atau menyerahkan Jasa Kena Pajak.

2. Jika Pajak Masukan lebih kecil dari Pajak Keluaran, maka selisihnya wajib disetor ke negara.

3. Jika Pajak Masukan lebih besar dari Pajak Keluaran, maka selisihnya bisa di restitusi atau di kompensasikan ke masa pajak berikutnya.

4. Laporan perhitungan Pajak Pertambahan Nilai dilaksanakan setiap masa pajak menggunakan SPT Masa PPN.

Tarif Pajak Pertambahan Nilai. Tarif PPN sesuai dengan Undang-Undang Nomor 42 Tahun 2009 Pasal 7 adalah:

1. Tarif $10 \%$.

2. Tarif ekspor $0 \%$.

3. Tarif dapat berubah menjadi paling besar $15 \%$ dan paling sedikit $5 \%$ berdasarkan Peraturan Pemerintah.

Faktur Pajak. Faktur Pajak adalah bukti tanda karena pajak telah dipungut saat melakukan penyerahan Barang Kena Pajak (BKP) atau Jasa Kena Pajak yang dibuat oleh Pengusaha Kena Pajak (Mardiasmo, 2018:338). E-Faktur Pajak adalah aplikasi perpajakan yang terbuat dari sistem elektronik yang bertujuan untuk memberi kemudahan dan juga kenyamanan bagi Pengusaha Kena Pajak dalam membuat faktur pajak. Direktorat Jenderal Pajak melalui keputusan No. KEP 136/PJ/2014 dan PER-16/PJ/2014 menetapkan pada bulan Juli 2015 Pengusaha Kena Pajak yang tercatat di Kantor Pelayanan Pajak (KPP) Jawa dan Bali harus sudah memakai e-Faktur, sedangkan pemberlakuan e-Faktur secara nasional akan serentak dimulai tanggal 1 Juli 2016.

Penyetoran dan Pelaporan Pajak Pertambahan Nilai

Penyetoran Pajak Pertambahan Nilai. Pihak yang harus melakukan penyetoran Pajak Pertambahan Nilai yakni Pengusaha Kena Pajak (PKP). Yang disetor adalah selisih dari Pajak Keluaran dan Pajak Masukan, bila Pajak Masukan lebih kecil dari Pajak Keluaran. Penyetoran bisa dilakukan melalui Kantor Pos dan Giro atau Bank Persepsi. Sarana penyetoran Pajak Pertambahan Nilai menggunakan Surat Setoran Pajak (SSP) yang tersedia di Kantor Pelayanan Pajak (KPP) dan Kantor Pelayanan Penyuluhan dan Konsultasi (KP2KP) diseluruh Indonesia. Pajak Pertambahan Nilai harus disetorkan paling lambat akhir bulan berikutnya setelah masa pajak berakhir.

Pelaporan Pajak Pertambahan Nilai. Direktorat Jenderal Pajak melakukan perubahan baru dengan memanfaatkan teknologi informasi maka dibuatlah sebuah aplikasi komputer untuk sistem administrasi perpajakan berupa e-SPT dan e-Filing yang berguna memudahkan wajib pajak, maka dengan begitu bisa meningkatkan kepatuhan Wajib Pajak dalam melaporkan pajaknya (Tumuli, Sondakh, dan Wokas:2016). Pada saat ini penyampaian SPT Masa PPN bisa dilakukan secara online menggunakan aplikasi e-SPT yang bisa diunduh pada situs Direktorat Jenderal Pajak (DJP). E-SPT merupakan penyampaian SPT Ke KPP berbentuk elektronik atau dengan menggunakan media komputer maka tidak perlu lagi datang ke Kantor Pelayanan Pajak (KPP) Pratama untuk mengantre dalam proses pelaporan pajak.

Kajian Penelitian Terdahulu. Effendy (2013) melakukan penelitian dengan judul Faktor-Faktor yang Mempengaruhi Ketidakpatuhan Wajib Pajak dalam Membayar Pajak Pertambahan Nilai. Penelitian ini bertujuan untuk mengetahui faktor-faktor apa yang 
mempengaruhi ketidakpatuhan Wajib Pajak dalam membayar Pajak Pertambahan Nilai secara signifikan. Menggunakan metode penelitian kuantitatif. Hasil dari penelitian ini yaitu terdapat 5 faktor yang mempengaruhi, yakni faktor kepercayaan atas kepastian hukum, faktor persepsi wajib pajak atas sanksi Pajak Pertambahan Nilai, faktor kondisi ekonomi perusahaan, faktor media massa dan politik, dan faktor kesadaran Pajak Pertambahan Nilai.

\section{METODE PENELITIAN}

Jenis Penelitian. Jenis penelitian yang digunakan penulis pada penelitian ini adalah penelitian kualitatif dengan pendekatan deskriptif. Penelitian ini mengeksplorasi dan memotret situasi yang akan diteliti secara luas dan mendalam, khususnya mengenai Pajak Pertambahan Nilai pada PT. Emigas Sejahtera.

Tempat dan Waktu Penelitian. Penelitian ini dilakukan di PT. Emigas Sejahtera yang beralamat di Winangun, Manado, Sulawesi Utara. Waktu dimulainya penelitian adalah pada bulan Agustus 2018 s/d selesainya.

\section{Jenis, Sumber dan Metode Pengumpulan Data}

Jenis Data. Jenis data yang digunakan dalam penelitian ini adalah:

1. Data kualitatif dalam penelitian ini berupa gambaran umum perusahaan dan penerapan Pajak Pertambahan Nilai.

2. Data kuantitatif dalam penelitian ini berupa data penjualan tahun 2017, data pembelian tahun 2017, dan data Pajak Pertambahan Nilai tahun 2017.

Sumber Data. Sumber data yang digunakan dalam penelitian ini adalah sumber data primer yang berupa data penjualan 2017, data pembelian 2017, dan data Pajak Pertambahan Nilai tahun 2017.

Metode Pengumpulan Data. Metode pengumpulan data yang digunakan dalam penelitian ini adalah:

1. Wawancara akan dilakukan kepada karyawan bagian perpajakan PT. Emigas Sejahtera. Wawancara dilakukan untuk mengetahui bagaimana perhitungan penyetoran dan pelaporan Pajak Pertambahan Nilai.

2. Dokumentasi dalam penelitian ini adalah rekap data pembelian tahun 2017, data penjualan tahun 2017, dan data Pajak Pertambahan Nilai tahun 2017.

Metode dan proses analisis. Metode analisis yang digunakan dalam penelitian ini adalah metode analisis deskriptif. Metode ini bertujuan untuk menguraikan, membandingkan, memberikan gambaran perusahaan dan menerangkan suatu data yang kemudian dianalisis, sehingga dapat membuat suatu kesimpulan sesuai dengan informasi dan data yang telah dikumpulkan. Proses analisisnya adalah:

1. Tahap awal, penulis mengambil data dari PT Emigas Sejahtera untuk memahami kondisi perusahaan khususnya kondisi perpajakan dari perusahaan.

2. Selanjutnya penulis melakukan analisis terhadap perhitungan Pajak Pertambahan Nilai yang sudah dilakukan PT. Emigas Sejahtera untuk melihat apakah perhitungannya telah berdasarkan Undang-Undang Nomor 42 Tahun 2009 yang berlaku.

3. Setelah menghitung PPN yang terutang, penulis kemudian menganalisis penyetoran dan pelaporan PPN di PT. Emigas Sejahtera.

4. Kemudian penulis mengambil kesimpulan atas analisis yang sudah dilaksanakan pada tahap-tahap sebelumnya.

5. Tahap terakhir dalam proses ini yaitu memberi saran apabila menemukan sesuatu yang harus dibetulkan oleh PT. Emigas Sejahtera, supaya menjadi lebih bagus dari sebelumnya. 


\section{HASIL PENELITIAN DAN PEMBAHASAN}

\subsection{Hasil Penelitian}

Gambaran Umum Perusahaan. PT. Emigas Sejahtera merupakan Agen LPG tabung $3 \mathrm{Kg}$ yang bekerja sama dengan PT. Pertamina kemudian menyalurkan LPG ke berbagai pangkalan di berada Kabupaten Minahasa. Didirikan di Kabupaten Minahasa pada tahun 2011 bersamaan dengan digulirkannya program konversi minyak tanah ke gas LPG di daerah Minahasa. Mitra usaha PT. Emigas Sejahtera mencakup beragam industri seperti, hotel-hotel, restoran-restoran atau rumah makan di wilayah Minahasa.

\section{Pelaksanaan Pajak Pertambahan Nilai Pada PT. Emigas Sejahtera}

1. Dasar Pengenaan Pajak (DPP). PT. Emigas Sejahtera menggunakan Harga Jual sebagai Dasar Pengenaan Pajak dalam melakukan perhitungan Pajak Pertambahan Nilai.

2. Tarif Pajak Pertambahan Nilai (PPN). Menggunakan tarif sesuai dengan Undang-Undang No. 42 Tahun 2009 yaitu sebesar $10 \%$.

3. Perhitungan Pajak Pertambahan Nilai (PPN). Dalam menghitung PPN, PT. Emigas Sejahtera menggunakan metode pengkreditan Pajak Masukan dan Pajak Keluaran. Ketika melaksanakan perhitungan besarnya Pajak Pertambahan Nilai yang harus dipungut serta disetorkan berdasarkan rumus sebagai berikut:

$$
\text { Pajak Pertambahan Nilai }=\text { Dasar Pengenaan Pajak x Tarif PPN 10\% }
$$

Pajak Masukan. Pajak Masukan dikenakan saat PT. Emigas Sejahtera membeli LPG 3kg kepada PT. Pertamina, maka PT. Emigas Sejahtera dipungut Pajak Masukan sebesar 10\% dari harga jual. Pada bulan April 2017, PT. Emigas Sejahtera membeli tabung LPG 3kg kepada PT. Pertamina seharga Rp. 1.569.729.000 (termasuk PPN). Maka perhitungan Pajak Pertambahan Nilainya adalah:

$$
\begin{array}{ll}
\text { DPP } & =100 / 110 \times \text { Rp. } 1.569 .729 .000 \\
& =\text { Rp. } 1.427 .026 .364 \\
\text { PPN Masukan } 10 \% & =10 / 110 \times \text { Rp. } 1.569 .729 .000 \\
& =\text { Rp. } 142.702 .636
\end{array}
$$

Jurnal untuk mencatat transaksi diatas adalah:

Pembelian Rp. 1.427.026.364

PPN Masukan Rp. 142.702.636

$$
\text { Kas } \quad \text { Rp. } 1.569 .729 .000
$$

Pajak Keluaran. Pajak Keluaran dikenakan pada saat PT. Emigas Sejahtera melakukan penjualan LPG 3kg kepada pangkalan-pangkalan yang berada di wilayah Kabupaten Minahasa, atas maka PT. Emigas Sejahtera memungut Pajak Keluaran sebesar 10\%. Pada bulan April 2017 PT. Emigas Sejahtera melakukan penjualan LPG 3kg sebanyak seharga Rp. 1.727.469.000 (termasuk PPN). Maka perhitungan Pajak Pertambahan Nilainya adalah sebagai berikut:

DPP

$$
\begin{array}{ll}
\text { DPP } & =100 / 110 \times \text { Rp. } 1.727 .469 .000 \\
& =\text { Rp. } 1.570 .426 .364 \\
\text { PPN Keluaran } 10 \% & =10 / 110 \times \text { Rp. } 1.727 .469 .000 \\
& =\text { Rp. } 157.042 .636
\end{array}
$$

Jurnal untuk mencatat transaksi diatas adalah:

Kas Rp. 1.727.469.000
Penjualan
Rp. 1.570.426.364
PPN Keluaran
Rp. 157.042.636

Berikut ini adalah Pajak Pertambahan Nilai (PPN) selama tahun 2017: 
Tabel 1. Data Penyerahan Barang Kena Pajak Tahun 2017

\begin{tabular}{lccc}
\hline \multirow{2}{*}{ Masa Pajak } & \multicolumn{3}{c}{ Penyerahan } \\
\cline { 2 - 4 } & \multicolumn{1}{c}{$\begin{array}{c}\text { Jumlah } \\
(\mathbf{R p})\end{array}$} & $\begin{array}{c}\text { DPP } \\
(\mathbf{R p})\end{array}$ & \multicolumn{1}{c}{$\begin{array}{c}\text { PPN 10\% } \\
(\mathbf{R p})\end{array}$} \\
\hline Januari & 1.799 .373 .000 & 1.635 .793 .636 & 163.579 .364 \\
Februari & 1.655 .565 .000 & 1.505 .059 .091 & 150.505 .909 \\
Maret & 1.869 .233 .000 & 1.699 .302 .727 & 169.930 .273 \\
April & 1.727 .469 .000 & 1.570 .426 .364 & 157.042 .636 \\
Mei & 1.801 .109 .000 & 1.637 .371 .818 & 163.737 .182 \\
Juni & 1.799 .976 .500 & 1.636 .342 .273 & 163.634 .227 \\
Juli & 1.869 .233 .000 & 1.699 .302 .727 & 169.930 .273 \\
Agustus & 1.873 .616 .500 & 1.703 .287 .727 & 170.328 .773 \\
September & 1.727 .469 .000 & 1.570 .426 .364 & 157.042 .636 \\
Oktober & 1.869 .233 .000 & 1.699 .302 .727 & 169.930 .273 \\
November & 1.873 .616 .500 & 1.703 .287 .727 & 170.328 .773 \\
Desember & 1.654 .961 .500 & 1.504 .510 .455 & 150.451 .045 \\
Total & $\mathbf{2 1 . 5 2 0 . 8 5 5 . 0 0 0}$ & $\mathbf{1 9 . 5 6 4 . 4 1 3 . 6 3 6}$ & $\mathbf{1 . 9 5 6 . 4 4 1 . 3 6 4}$ \\
\hline
\end{tabular}

Sumber: Rincian PPN Keluaran Tahun 2017 PT. Emigas Sejahtera

Tabel 1 menunjukkan bahwa total penjualan LPG $3 \mathrm{~kg}$ PT. Emigas Sejahtera kepada pangkalan-pangkalan yang ada di Kabupaten Minahasa sebesar Rp. 21.520.855.000,termasuk PPN, sehingga DPP sebesar Rp. 19.564.413.636,- dan menghasilan Pajak Keluaran sebesar Rp. 1.956.441.364,- sehingga perhitungan jumlah Pajak Pertambahan Nila sudah dilakukan dengan benar berdasarkan aturan yang berlaku.

Tabel 2. Data Penerimaan Barang Kena Pajak Tahun 2017

\begin{tabular}{lccr}
\hline \multirow{2}{*}{ Masa Pajak } & \multicolumn{3}{c}{ Penerimaan } \\
\cline { 2 - 4 } & $\begin{array}{l}\text { Jumlah } \\
(\mathbf{R p})\end{array}$ & $\begin{array}{c}\text { DPP } \\
(\mathbf{R p})\end{array}$ & $\begin{array}{c}\text { PPN 10\% } \\
(\mathbf{R p})\end{array}$ \\
\hline Januari & 1.637 .153 .000 & 1.488 .320 .909 & 148.832 .091 \\
Februari & 1.502 .305 .000 & 1.365 .731 .818 & 136.573 .182 \\
Maret & 1.702 .533 .000 & 1.547 .757 .273 & 154.775 .727 \\
April & 1.569 .729 .000 & 1.427 .026 .364 & 142.702 .636 \\
Mei & 1.638 .889 .000 & 1.489 .899 .091 & 148.989 .909 \\
Juni & 1.629 .386 .500 & 1.481 .260 .455 & 148.126 .045 \\
Juli & 1.702 .533 .000 & 1.547 .757 .273 & 154.775 .727 \\
Agustus & 1.698 .546 .500 & 1.544 .133 .182 & 154.413 .318 \\
September & 1.569 .729 .000 & 1.427 .026 .364 & 142.702 .636 \\
Oktober & 1.702 .533 .000 & 1.547 .757 .273 & 154.775 .727 \\
November & 1.698 .546 .500 & 1.544 .133 .182 & 154.413 .318 \\
Desember & 1.510 .071 .500 & 1.372 .792 .273 & 137.279 .227 \\
Total & $\mathbf{1 9 . 5 6 1 . 9 5 5 . 0 0 0}$ & $\mathbf{1 7 . 7 8 3 . 5 9 5 . 4 5 5}$ & $\mathbf{1 . 7 7 8 . 3 5 9 . 5 4 5}$ \\
\hline Sumber: Rincis
\end{tabular}

Sumber: Rincian PPN Masukan tahun 2017 PT. Emigas Sejahtera

Berdasarkan pada Tabel 2, besarnya total pembelian LPG 3kg PT. Emigas Sejahtera kepada PT. Pertamina sebesar Rp. 19.561.955.000,- termasuk PPN, sehingga DPP sebesar Rp. 17.783.595.455,- dan menghasilan Pajak Masukan sebesar Rp. 1.778.359.545,- Dengan demikian perhitungan jumlah Pajak Pertambahan Nilai sudah sudah dilakukan dengan benar berdasarkan aturan yang berlaku. Untuk menghitungan besarnya Pajak Pertambahan Nilai lebih bayar ataupun kurang bayar bisa dihitung menggunakan rekapan data Pajak Masukan 
dan Pajak Keluaran dalam Tabel 3. Berikut adalah perhitungan besarnya Pajak Pertambahan Nilai yang terutang (kurang/lebih bayar) pada tahun 2017 PT. Emigas Sejahtera:

Tabel 3. Perhitungan Pajak Pertambahan Nilai Tahun 2017

\begin{tabular}{|c|c|c|c|c|}
\hline Masa Pajak & $\begin{array}{c}\text { Pajak Keluaran } \\
\text { (Rp) }\end{array}$ & $\begin{array}{c}\text { Pajak Masukan } \\
\text { (Rp) }\end{array}$ & $\begin{array}{c}\text { Kompensasi } \\
(\mathbf{R p})\end{array}$ & $\begin{array}{c}\text { Kurang/Lebih } \\
\text { bayar } \\
\text { (Rp) }\end{array}$ \\
\hline Januari & 163.579 .364 & 148.832 .091 & - & 14.747 .273 \\
\hline Februari & 150.505 .909 & 136.573.182 & - & 13.932 .727 \\
\hline Maret & 169.930 .273 & 154.775 .727 & - & 15.154 .545 \\
\hline April & 157.042 .636 & 142.702 .636 & - & 14.340 .000 \\
\hline Mei & 163.737 .182 & 148.989 .909 & - & 14.747 .273 \\
\hline Juni & 163.634.227 & 148.126 .045 & - & 15.508 .182 \\
\hline Juli & 169.930 .273 & 154.775 .727 & - & 15.154 .545 \\
\hline Agustus & 170.328 .773 & 154.413 .318 & - & 15.915 .455 \\
\hline September & 157.042 .636 & 142.702 .636 & - & 14.340 .000 \\
\hline Oktober & 169.930 .273 & 154.775 .727 & - & 15.154 .545 \\
\hline November & 170.328 .773 & 154.413 .318 & - & 15.915 .455 \\
\hline Desember & 150.451 .045 & 137.279.227 & - & 13.171 .818 \\
\hline Total & 1.956.441.364 & 1.778.359.545 & - & 178.081.818 \\
\hline
\end{tabular}

Sumber: Data Olahan

Berdasarkan Tabel 3, dapat dilihat besarnya Pajak Keluaran tahun 2017 PT. Emigas Sejahtera berjumlah Rp. 1.956.441.364.- Pajak Masukan tahun 2017 berjumlah Rp. 1.778.359.545.Berdasarkan hasil perhitungan keseluruhan Pajak Pertambahan Nilai didapati bahwa pada tahun 2017 tidak terjadi lebih bayar tetapi terjadi kurang bayar berjumlah Rp. 178.081.818.

\section{Mekanisme Kredit Pajak, Penyetoran Serta Pelaporan SPT Masa PPN}

1. Mekanisme Kredit Pajak. PT. Emigas Sejahtera menggunakan mekanisme kredit pajak setiap akhir bulan dengan membandingkan Pajak Keluaran yang telah dipungut dengan Pajak Masukan yang diperoleh. Kemudian menghitung apakah terjadi kurang bayar atau lebih bayar, selanjutnya dilaporkan ke SPT Masa PPN. Contoh: Pada bulan april 2017, jumlah Pajak Keluaran PT. Emigas Sejahtera berjumlah Rp. 157.042.636.- jumlah Pajak Masukan berjumlah Rp. 142.702.636.- maka bisa dihitung:
Pajak Keluaran
$=$ Rp. 157.042 .636
Pajak Masukan
$=$ Rp. 142.702 .636
PPN kurang bayar
$=$ Rp. 14.340 .000

Sesuai perhitungan diatas, maka PPN Masukan lebih kecil dari PPN Keluaran maka terjadi kurang bayar. Jurnalnya berikut ini:
PPN Keluaran
PPN Masukan
Rp. 157.042.636
PPN Kurang Bayar
Rp. 142.702.636
Rp. 14.340 .000

PPN kurang bayar tadi wajib di setorkan ke kas negara. Jurnal pada saat menyetorkan PPN kurang bayar yakni:
Hutang PPN
Rp. 14.340.000

Kas di Bank

Rp. 14.340 .000

2. Penyetoran Pajak Pertambahan Nilai. Wajib Pajak harus melakukan penyetoran besarnya Pajak Pertambahan Nilai yang kurang bayar kepada negara pada setiap Masa Pajak Pertambahan Nilai, atau bisa direstitusi atau dikompensasikan pada Masa Pajak bulan berikutnya jika terjadi lebih bayar. Seusai dengan Undang-Undang No. 42 Tahun 2009, Pajak Pertambahan Nilai wajib disetor selambat-lambatnya akhir bulan berikutnya setelah Masa Pajak berakhir dan juga sebelum Surat Pemberitahuan Masa disampaikan. Jika 
perusahaan tidak menyetorkan Pajak Pertambahan Nilainya sesuai dengan ketentuan perpajakan, maka berdasarkan Pasal 9 Undang-Undang Nomor 16 Tahun 2009 tentang Ketentuan Umum dan Tata Cara Perpajakan Ayat 2a, akan dikenai sanksi administrasi sebesar 2\% dari jumlah pajak terutang dimulai sejak tanggal jatuh tempo pembayaran sampai tanggal pembayaran. Berikut ini penjelasan apakah Pajak Pertambahan Nilai sudah disetor oleh PT. Emigas Sejahtera berdasarkan Undang-Undang yang berlaku:

Tabel 4. Penyetoran PPN PT. Emigas Sejahtera Tahun 2017

\begin{tabular}{lcll}
\hline \multicolumn{1}{c}{ Masa Pajak } & $\begin{array}{c}\text { Kurang Bayar } \\
(\mathbf{R p})\end{array}$ & \multicolumn{1}{c}{ Tanggal Setor PPN } & $\begin{array}{c}\text { Keterangan (Kesesuaian } \\
\text { dengan UU PPN No. 42 } \\
\text { Tahun 2009) }\end{array}$ \\
\hline Januari & 14.747 .273 & 20 Februari 2017 & Sudah Sesuai UU \\
Februari & 13.932 .727 & 20 Maret 2017 & Sudah Sesuai UU \\
Maret & 15.154 .545 & 20 April 2017 & Sudah Sesuai UU \\
April & 14.340 .000 & 22 Mei 2017 & Sudah Sesuai UU \\
Mei & 14.747 .273 & 20 Juni 2017 & Sudah Sesuai UU \\
Juni & 15.508 .182 & 20 Juli 2017 & Sudah Sesuai UU \\
Juli & 15.154 .545 & 21 Agustus 2017 & Sudah Sesuai UU \\
Agustus & 15.915 .455 & 20 Oktober 2017 & Belum Sesuai UU \\
September & 14.340 .000 & 20 Oktober 2017 & Sudah Sesuai UU \\
Oktober & 15.154 .545 & 20 November 2017 & Sudah Sesuai UU \\
November & 15.915 .455 & 20 Desember 2017 & Sudah Sesuai UU \\
Desember & 13.171 .818 & 22 Januari 2018 & Sudah Sesuai UU \\
\hline
\end{tabular}

Sumber: Data Olahan

Berdasarkan Tabel 4, selama tahun 2017 PT. Emigas Sejahtera pernah terlambat dalam menyetorkan Pajak Pertambahan Nilai yaitu Masa Pajak bulan agustus disetorkan bersamaan dengan Masa Pajak bulan september yaitu pada bulan oktober, jadi konsekuensinya dikenakan sanksi administrasi berupa denda sesuai Undang-Undang yang berlaku sebesar $2 \%$ dari jumlah pajak terutang.

3. Pelaporan Pajak Pertambahan Nilai. Berdasarkan peraturan Undang-Undang No. 42 Tahun 2009, Surat Pemberitahuan Masa disampaikan selambat-lambatnya akhir bulan berikutnya setelah Masa Pajak berakhir. Apabila Perusahaan terlambat dalam melaporkan SPT Masa PPN, maka perusahaan akan dikenakan sanksi berjumlah Rp. 500.000.- sesuai dengan peraturan pasal 7 ayat 1 Undang-Undang No. 16 Tahun 2009 tentang Ketentuan Umum dan Tata Cara Perpajakan. SPT Masa PPN 1111 DM dilaporkan oleh PKP yang menggunakan Pedoman Perhitungan Pengkreditan Pajak Masukan. Berikut ini adalah penjabaran mengenai apakah PT. Emigas Sejahtera telah melaporkan SPT Masa Pajak Pertambahan Nilai sudah sesuai atau tidak sesuai dengan Undang-Undang yang berlaku: 
Tabel 5. Pelaporan PPN PT. Emigas Sejahtera

\begin{tabular}{lcll}
\hline Masa Pajak & $\begin{array}{c}\text { Kurang Bayar } \\
(\mathbf{R p})\end{array}$ & Tanggal Lapor PPN & $\begin{array}{c}\text { Keterangan (Kesesuaian } \\
\text { dengan UU PPN No. 42 } \\
\text { Tahun 2009) }\end{array}$ \\
\hline Januari & 14.747 .273 & 22 Februari 2017 & Sudah Sesuai UU \\
Februari & 13.932 .727 & 22 Maret 2017 & Sudah Sesuai UU \\
Maret & 15.154 .545 & 21 April 2017 & Sudah Sesuai UU \\
April & 14.340 .000 & 24 Mei 2017 & Sudah Sesuai UU \\
Mei & 14.747 .273 & 22 Juni 2017 & Sudah Sesuai UU \\
Juni & 15.508 .182 & 24 Juli 2017 & Sudah Sesuai UU \\
Juli & 15.154 .545 & 23 Agustus 2017 & Sudah Sesuai UU \\
Agustus & 15.915 .455 & 23 Oktober 2017 & Belum Sesuai UU \\
September & 14.340 .000 & 23 Oktober 2017 & Sudah Sesuai UU \\
Oktober & 15.154 .545 & 22 November 2017 & Sudah Sesuai UU \\
November & 15.915 .455 & 22 Desember 2017 & Sudah Sesuai UU \\
Desember & 13.171 .818 & 24 Januari 2018 & Sudah Sesuai UU \\
\hline
\end{tabular}

Sumber: Data Olahan

Berdasarkan Tabel 5 diatas, didapati bahwa selama tahun 2017 PT. Emigas Sejahtera pernah terlambat dalam melaporkan Pajak Pertambahan Nilainya yaitu Masa Pajak bulan agustus sehingga harus membayar sanksi administrasi berupa denda berjumlah Rp. 500.000.- sesuai Undang-Undang yang berlaku.

\subsection{Pembahasan}

PT. Emigas Sejahtera sebagai PKP wajib membuat Faktur Pajak pada saat diterimanya pembayaran. Pajak Masukan dan Keluaran PT. Emigas Sejahtera menggunakan e-Faktur sebagai sarana untuk membuktikan pungutan pajak. Mekanisme pengkreditan yang dilaksanakan oleh PT. Emigas Sejahtera setiap akhir bulan dengan melakukan perbandingan Pajak Keluaran yang telah dipungut menggunakan Faktur Pajak dengan Pajak Masukan yang diperoleh menggunakan Faktur Pajak. E-Faktur yang dibuat oleh PT. Emigas Sejahtera telah sesuai dengan ketentuan yang berlaku. Berdasarkan hasil penelitian pada PT. Emigas Sejahtera, perhitungan Pajak Pertambahan Nilai pada PT. Emigas Sejahtera sudah sesuai dengan Undang-Undang No. 42 Tahun 2009 tentang Pajak Pertambahan Nilai. Diantaranya penetapan Dasar Pengenaan Pajak menggunakan harga jual, dan tarif pajak yang digunakan oleh PT. Emigas Sejahtera sebesar 10\% dari Dasar Pengenaan Pajak.

Untuk penyetoran dan pelaporan Pajak Pertambahan Nilai yang dilakukan oleh PT. Emigas Sejahtera pada tahun 2017 pernah terjadi keterlambatan alasannya kurangnya tenaga kerja di bagian perpajakan yaitu hanya berjumlah 1 orang, sehingga kalau karyawan tersebut sakit, tidak ada yang menggantikannya sehingga terjadi keterlambatan dalam penyetoran dan pelaporan yaitu pada Masa Pajak bulan agustus yang seharusnya disetorkan dan dilaporkan pada bulan september 2017 tapi disetorkan pada tanggal 22 oktober 2017 dan dilaporkan pada tanggal 23 oktober 2018 bersamaan dengan Masa Pajak bulan september. Karena keterlambatan penyetoran Pajak Pertambahan Nilai, maka PT. Emigas Sejahtera dikenakan sanksi administrasi berupa denda sesuai Undang-Undang yang berlaku sebesar $2 \%$ dari jumlah pajak yang terutang bulan agustus yaitu sebesar Rp. 318.309.- Selain melakukan perhitungan sendiri besarnya Pajak Pertambahan Nilai berdasarkan peraturan yang ditetapkan, PT. Emigas Sejahtera juga melakukan penyetoran atau membayar sendiri jumlah pajaknya melalui Bank Mandiri. Karena terjadi keterlambatan pelaporan Pajak Pertambahan Nilai (PPN) maka dikenakan sanksi administrasi sebesar Rp. 500.000.- PT. Emigas Sejahtera 
melaporkan Pajak Pertambahan Nilai yang telah dipungut dan disetor dilakukan secara online melalui aplikasi e-SPT menggunakan SPT Masa PPN 1111 DM.

\section{KESIMPULAN DAN SARAN}

\subsection{Kesimpulan}

1. Perhitungan Pajak Pertambahan Nilai yang dilaksanakan oleh PT. Emigas Sejahtera sudah sesuai dengan Undang-Undang No. 42 Tahun 2009 tentang Pajak Pertambahan Nilai.

2. PT. Emigas Sejahtera pernah terjadi keterlambatan dalam menyetorkan dan melaporkan Pajak Pertambahan Nilainya disebabkan karena kurangnya tenaga kerja di bagian perpajakan untuk menyetor dan melaporkan Pajak Pertambahan Nilai.

3. PT. Emigas Sejahtera sebagai perusahaan yang telah terdaftar sebagai Pengusaha Kena Pajak (PKP) sudah memenuhi kewajibannya dalam bidang perpajakan yaitu dengan menyetorkan Pajak Pertambahan Nilai melalui bank persepsi dan melaporkan pajak terutang secara online melalui aplikasi e-SPT sesuai dengan Peraturan Perpajakan yang berlaku.

\subsection{Saran}

Berdasarkan kesimpulan diatas maka dapat diberikan saran-saran sebagai berikut:

1. PT. Emigas Sejahtera harus terus mengikuti seluruh kemajuan dan perubahan yang akan terjadi dalam aturan perpajakan, karena aturan dan ketentuan pajak seringkali terjadi perubahan yang berguna untuk mempermudah proses perpajakan di Indonesia.

2. Untuk mencegah diberlakukannya sanksi administrasi karena terjadi keterlambatan dalam menyetorkan dan melaporkan Pajak Pertambahan Nilai, seharusnya PT. Emigas Sejahtera menambah 1 orang karyawan di bagian perpajakan sehingga masalah keterlambatan dapat teratasi.

\section{DAFTAR PUSTAKA}

Effendy, T S. dan Toly, A A. 2013. Faktor-Faktor yang Mempengaruhi Ketidakpatuhan Wajib Pajak dalam Membayar Pajak Pertambahan Nilai. Tax and Accounting Review. Vol. 1 No. 1.

Keputusan Direktur Jenderal Pajak Nomor KEP-136/PJ/2014. Penetapan Pengusaha Kena Pajak Yang Diwajibkan Membuat Faktur Pajak Berbentuk Elektronik. 20 Juni 2014. Jakarta.

Mardiasmo. 2018. Perpajakan. Edisi Terbaru 2018. Andi. Yogyakarta.

Undang-Undang Republik Indonesia Nomor 16 Tahun 2009. Ketentuan Umum dan Tata Cara Perpajakan. 25 Maret 2009. Lembaran Negara Republik Indonesia Tahun 2009 Nomor 62. Jakarta.

Undang-Undang Republik Indonesia Nomor 42 Tahun 2009. Pajak Pertambahan Nilai Barang dan Jasa dan Pajak Penjualan atas Barang Mewah (PPN dan PPnBM). 15 Oktober 2009. Lembaran Negara Republik Indonesia Tahun 2009 Nomor 150. Jakarta.

Peraturan Direktur Jenderal Pajak Nomor PER-16/PJ/2014. Tata Cara Pembuatan Dan Pelaporan Faktur Pajak Berbentuk Elektronik. 20 Juni 2014. Jakarta.

Peraturan Menteri Keuangan Republik Indonesia Nomor 197/PMK.03/2013. Batasan Pengusaha Kecil Pajak Pertambahan Nilai. 20 Desember 2013. Berita Negara Republik Indonesia Tahun 2013 Nomor 1521. Jakarta.

Pontoh, W. 2013. Akuntansi Konsep dan Aplikasi. Halaman Moeka. Jakarta.

Resmi, S. 2013. Perpajakan: Teori dan Kasus. Edisi 7. Salemba Empat. Jakarta. 
Tumuli, A K. Sondakh, J J. dan Wokas, H. 2016. Analisis Penerapan E-SPT dan E-Filing Dalam Upaya Peningkatan Kepatuhan Wajib Pajak (Studi Kasus Di Kantor Pelayanan Pajak Pratama Manado). Jurnal EMBA: Jurnal Riset Ekonomi, Manajemen, Bisnis Dan Akuntansi. Vol. 4 No. 3.

Waluyo. 2017. Perpajakan Indonesia. Edisi 12 Buku 1. Salemba Empat. Jakarta.

Warren, C S. Reeve, J M. dan Duchac, J. 2017. Pengantar Akuntansi 1 Adaptasi Indonesia Edisi 4. Salemba Empat. Jakarta. 